\title{
JAK W KRZYWYM ZWIERCIADLE. PRZEKŁADOWY OBRAZ FRANCUSKIEJ LITERATURY DLA DZIECI I MŁODZIEŻY W POLSCE PO ROKU 1918'
}

\begin{abstract}
Like in a Distorting Mirror. The Translation Image of French Children's Literature in Poland after 1918

"Translation is one of the core practices through which any cultural group constructs representations of another" (Baker 2014: 15). The shape of these images is influenced by the selection of translated source culture texts, and by the translation itself, i.e. the way it was achieved. In the case of literature, publishers are largely responsible for the selection of translated works, and translators for the choice of the solutions implemented in the text.

This article focuses on the publishers' choices and their impact on the image of the source literature presented to the target culture readers. I analyzed from this point of view the history of translation of French children's literature from 1918-2014. The research was carried out using a bibliometric approach. The period under consideration was divided into three shorter ones: the Second Republic (1918-1944), People's Poland (1945-1989) and the Third Republic (from 1990). For each of them (a) I presented the situation of the publishing market and children's literature at that time, (b) I defined the place of translated French children's literature against the background of the entire production available for this group of readers, (c) I presented the choices of the publishers
\end{abstract}

${ }^{1}$ Niniejszy artykuł zawiera syntetyczne opracowanie wyników badań, których szersze omówienie ukazało się w monografii Sto lat przekładów dla dzieci i młodzieży w Polsce. Francuska literatura dla młodych czytelników, jej polscy wydawcy i ich strategie (19182014) (Paprocka 2018b). Badania zostały sfinansowane przez Narodowe Centrum Nauki W ramach projektu nr 2012/05/B/HS2/04042. 
of Polish translations, paying special attention to "white spots" and deformations in the translation import.

The conclusions show an inadequacy between the actual shape and character of French children's literature in the last century and the image of this literature presented to its Polish audience due to the choices of the publishers of the translations.

Keywords: French children's literature, Polish translations, translation history, translation publishers, bibliometric method

Słowa kluczowe: francuska literatura dla dzieci i młodzieży, polskie tłumaczenia, historia przekładów, wydawcy przekładów, metoda bibliometryczna

\section{Uwagi wstępne}

Przekład - jak pisze Mona Baker (2014: 15) - stanowi podstawowe narzędzie, za pomocą którego członkowie społeczności kulturowych tworzą swoje wyobrażenia (representations) innych kultur. Na kształt tych obrazów wpływ ma zarówno wybór tekstów kultury źródłowej udostępnianych w przekładach, jak i sposób, w jaki tłumaczenia zostały wykonane. W przypadku literatury obcej za selekcję utworów do tłumaczenia odpowiadają zazwyczaj wydawcy przekładów, natomiast dobór rozwiązań tekstowych (podporządkowanych strategiom tłumaczeniowym) pozostaje w gestii tłumaczy.

W niniejszym artykule w centrum zainteresowania znajdują się wybory pierwszego rodzaju oraz ich wpływ na obraz literatury źródłowej u członków kultury docelowej. Ponieważ przekład rozumiany jest jako praktyka społeczna (Wolf 2010: 337), a wydawcy przekładów są - podobnie jak tłumacze - członkami społeczności, ich decyzje postrzegane są jako zależne nie tylko od ich osobistych preferencji, ale również - czy może przede wszystkim - od szerszego kontekstu społeczno-kulturowego.

Z takiej perspektywy analizowane są przekładowe losy francuskiej literatury dla dzieci i młodzieży, za sprawą której w XVIII wieku do Polski po raz pierwszy na szerszą skalę dotarło piśmiennictwo dla młodych czytelników. Z języka francuskiego thumaczono wówczas przeznaczone dla niedorosłych utwory pisarzy nie tylko francuskich, ale również niemieckich czy angielskich (Kaniowska-Lewańska 1973: 31). Francja, gdzie tworzyli już François Fénélon, Jeanne-Marie Leprince de Beaumont, Stéphanie Félicité de Genlis i Arnaud Berquin, odgrywała w ówczesnej Europie dominującą rolę, jeśli chodzi o literaturę dla tej grupy czytelniczej - ze względu na swoją 
dominację polityczną, ale też za sprawą migrujących po uchyleniu edyktu nantejskiego w 1685 roku niekatolickich nauczycieli języka francuskiego, zatrudnianych w majętnych domach całej Europy. Upowszechniali oni dorobek francuskich pisarzy adresujących swoją twórczość do niedorosłych i francuskie przeróbki z literatury powszechnej (Nikliborc 1981: 19).

Oryginalna polska literatura dla dzieci i młodzieży wyłoniła się w zasadzie dopiero w pierwszym ćwierćwieczu XIX wieku, wraz z twórczością Klementyny z Tańskich Hoffmanowej i Stanisława Jachowicza, wykorzystujących zresztą nierzadko przystosowane do rodzimych warunków obce wzorce. Przez cały wiek XIX nadal systematycznie przekładano na polski wiele francuskich utworów dla tej grupy czytelniczej i to dość szybko po wydaniu oryginałów, czego przykładem były powieści Jules’a Verne’a, mające polską premierę czasem już w tym samym roku, w którym ukazywały się we Francji.

Jednak od przełomu XIX i XX wieku, kiedy francuska literatura dla młodych czytelników weszła w czas kryzysu (Nières-Chevrel 2009: 43), ten kierunek zapożyczeń literackich zaczął stopniowo tracić na znaczeniu. Zmiana ta pozostawała w ścisłym związku ze zmianami układu sił w Europie i na świecie, w wyniku których język francuski utracił zajmowaną przez kilka wieków dominującą pozycję, a w roli lingua franca zastąpił go angielski, szczególnie po konferencji pokojowej w Paryżu (1919-1920). W Polsce ogromne znaczenie miał powrót do suwerenności państwowej, bo, jak podkreśla Jan Wnęk, „stworzył zupełnie nowe warunki dla recepcji obcej literatury" (2006: 21, 65).

Diametralnie różny kontekst polityczno-historyczny po roku 1918 sprawia, że przekłady francuskiej literatury dla dzieci i młodzieży w niepodległej Polsce zasługują na uwagę, bo choć straciły wiodącą pozycję, to jednak pozostały integralną częścią polskiego systemu literackiego dla niedorosłych. Celem opisanego w niniejszym artykule badania, sytuującego się w obszarze archeologii przekładu (Pym 1998: 5-6), jest próba odpowiedzi na pytanie, jak Polacy - za sprawą wyborów wydawców przekładów - mogli postrzegać francuską literaturę dla dzieci i młodzieży w ciągu ostatniego stulecia, oraz sprawdzenie, na ile obraz ten był zgodny z rzeczywistością.

Aby móc odpowiedzieć na tak sformułowane pytania, trzeba przede wszystkim ustalić listę tłumaczeń utworów francuskiej literatury dla dzieci i młodzieży, które wydawcy udostępniali polskim czytelnikom w najnowszym stuleciu. Do tego celu wykorzystana została metoda bibliometryczna, na której użyteczność w diachronicznych badaniach przekładoznawczych 
wskazywał Pym (1998: 72-86), a w Polsce - Elżbieta Skibińska (2015). Polega ona na analizie danych bibliograficznych opublikowanych przekładów, najczęściej zebranych w bibliografiach. Ponieważ jednak nie istniał żaden kompletny wykaz bibliograficzny polskich przekładów francuskiej literatury dla dzieci i młodzieży, podstawą przeprowadzonego badania stała się lista, którą opracowałam samodzielnie na podstawie wielu źródeł ${ }^{2}$. Obejmuje ona łącznie 1915 wydań ponad 840 utworów francuskich, których tłumaczenia i adaptacje polscy wydawcy kierowali do czytelników niedorosłych ${ }^{3}$.

Po ustaleniu repertuaru dostępnych przekładów kolejnym krokiem było odniesienie wyborów polskich wydawców do całości literatury dla młodych czytelników powstającej we Francji w ostatnim stuleciu (piszą o niej m.in. Nières-Chevrel 2009, Ottevaere-Van Praag 2000, Escarpit 2008 czy Brown 2008). Porównanie takie pozwoliło na ustalenie białych plam i zniekształceń w przekładowym imporcie, czyli tych utworów czy nurtów, które wydawcy w swoich wyborach pominęli lub które za ich sprawą stały się w kulturze docelowej bardziej lub mniej popularne niż w kulturze źródłowej. Tego rodzaju rozbieżności mogły mieć wpływ na całościowy obraz francuskiej literatury dla młodych odbiorców, który tworzyli sobie polscy odbiorcy na podstawie dostępnych tłumaczeń.

\section{Periodyzacja - wątpliwości i rozstrzygnięcia}

Choć historycy przekładu przestrzegają przed bezkrytycznym stosowaniem chronologii historii politycznej w badaniach przekładów (np. Pym 1998: 56-57), to jednak często wzajemna zależność zjawisk przekładowych i polityczno-historycznych jest na tyle ścisła, że nie sposób jej pominąć. Istnienie takich korelacji zaobserwowała na przykład Ioana Popa, która badała mechanizmy rządzące transferem literackim z krajów Europy Środkowej i Wschodniej do Francji w latach 1947-1989:

${ }^{2}$ Były to: katalogi zbiorów bibliotecznych (Biblioteki Narodowej, Muzeum Książki Dziecięcej w Warszawie, Zakładu Narodowego im. Ossolińskich we Wrocławiu, polskich bibliotek uniwersyteckich i publicznych), istniejące wykazy bibliograficzne (m.in. Łasiewicka, Neubert 1971; Bębenek i in. 1977-1978, 1983; Krassowska, Grefkowicz 1995; Łachaciński, Zydorczak 1998; Wnęk 2006), strony internetowe wydawnictw i antykwariatów.

${ }^{3}$ Opracowana lista opublikowana została pod tytułem Bibliografia polskich przekładów $i$ adaptacji francuskiej literatury dla dzieci i młodzieży wydanych w latach 1918-2014 (Paprocka 2018a). 
[w]łaściwością kryzysów politycznych jest to, że synchronizują rytmy poszczególnych obszarów, w przeciwieństwie do sytuacji standardowych, których rytm jest dla danego obszaru specyficzny z powodu względnej autonomii poszczególnych sfer przestrzeni społecznej (Popa 2010: 162; tłum. Elżbieta Skibińska).

Silny wpływ czynników zewnątrzliterackich na import przekładowy widoczny jest również w przypadku francuskiej literatury dla dzieci i młodzieży obecnej w Polsce w ostatnim stuleciu. Odmienny charakter produkcji w tej dziedzinie w różnych okresach uwidacznia wykres 1 (na następnej stronie), na którym przedstawiono dla kolejnych pięcioleci liczbę wydań (pierwszych i wznowień) polskich przekładów francuskiej literatury dla młodych czytelników z wyodrębnieniem udziału poszczególnych wydawców.

Zmienna liczba wydań w latach 1918-1944 wyraźnie kontrastuje z ilościową stabilizacją w kolejnym półwieczu, a ta z kolei - z dynamicznym wzrostem liczby wydań po roku 1989. W dwóch pierwszych okresach przekłady francuskiej literatury dla dzieci i młodzieży publikowały zupełnie różne oficyny, różny był też ich wkład w całość oferty francuskiej: z dużym rozdrobnieniem w okresie międzywojennym kontrastuje monopol jednego wydawnictwa w okresie Polski Ludowej. Trzeci okres charakteryzuje powrót do rozdrobnienia produkcji między różnych wydawców, ale z wyraźną dominacją kilku oficyn.

Wyodrębniony na podstawie charakteru produkcji przekładowej i udziału różnych jej producentów okres pierwszy pokrywa się z okresem Rzeczpospolitej Polskiej (II Rzeczpospolitej), kolejny koresponduje z czasem, kiedy państwo polskie funkcjonowało pod propagandową nazwą Polska Ludowa $^{4}$, natomiast ostatni okres rozpoczyna się w roku 1990, czyli wraz z zasadniczymi przemianami politycznymi i gospodarczymi, do których doszło w Polsce po roku 1989. Państwo polskie wróciło wtedy do nazwy Rzeczpospolita Polska, choć dla podkreślenia ciągłości z okresem międzywojennym stosowane jest również określenie III Rzeczpospolita. Cezura końcowa - rok 2014 - wynika z tego, że był to ostatni rok, za który dostępne były informacje Biblioteki Narodowej w czasie opracowywania danych.

Dalsza część artykułu zawiera - dla każdego z trzech okresów - (a) zarys szerszego tła, czyli sytuacji rynku wydawniczego oraz literatury dla dzieci i młodzieży w Polsce, (b) określenie miejsca, jakie zajmowała

${ }^{4}$ Oficjalną nazwą kraju do roku 1952 była Rzeczpospolita Polska, a w latach 19521989 - Polska Rzeczpospolita Ludowa. 


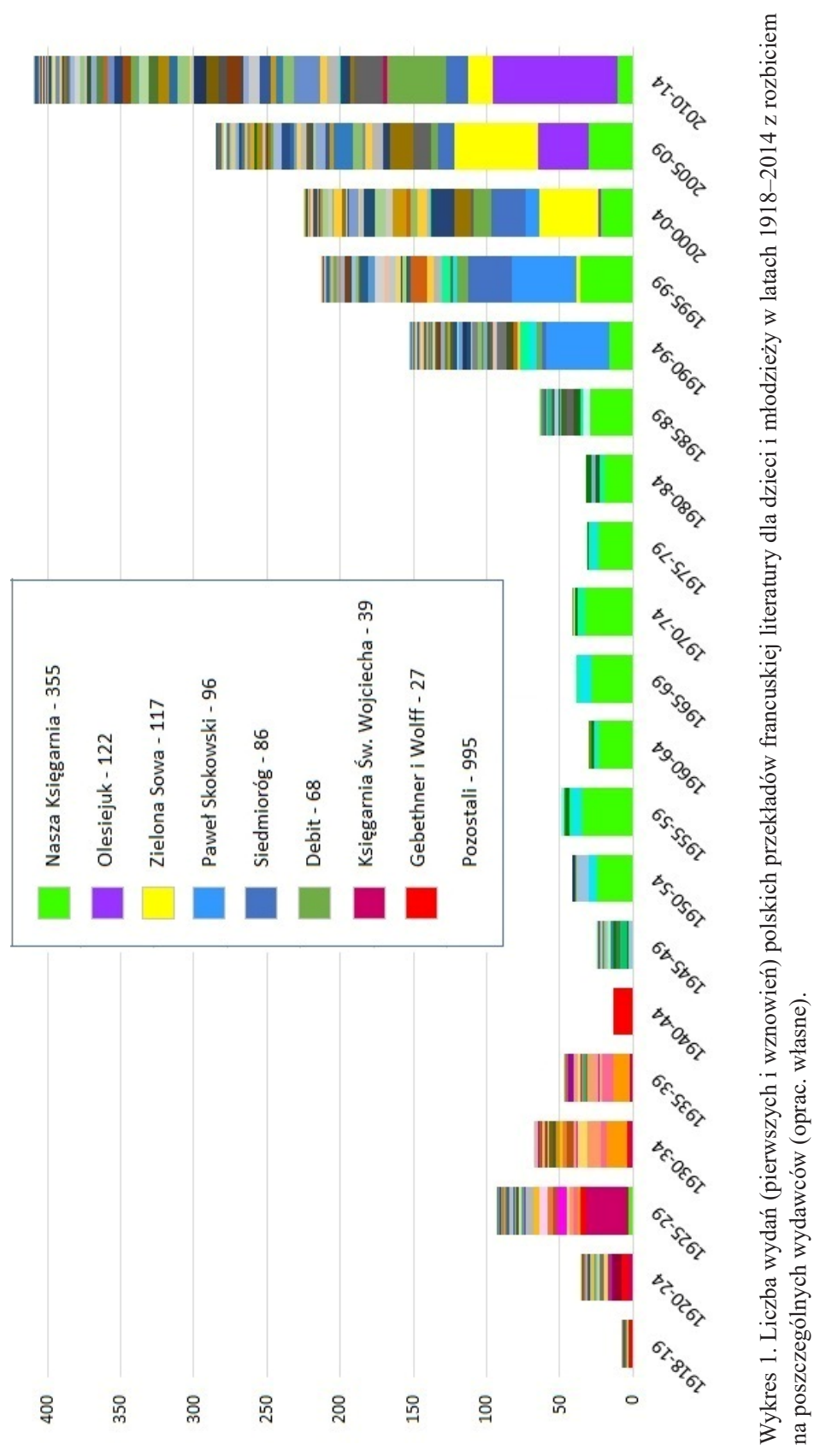


francuska literatura dla dzieci i młodzieży na tle całej produkcji dla tej grupy czytelniczej, (c) przedstawienie wyborów wydawców jej polskich przekładów oraz zasygnalizowanie białych plam i zniekształceń w przekładowym imporcie.

\section{Rzeczpospolita (1918-1944)}

W kraju, który odzyskał niepodległość, zapotrzebowanie na książki w języku polskim było ogromne, i to mimo ogólnie niesprzyjających warunków (inflacja, kryzys gospodarczy, brak papieru). Na rynku doszło do eksplozji przedsiębiorczości polskich wydawców, szczególnie w drugiej połowie lat 20. XX wieku. Ogólnoświatowa koniunktura gospodarcza była sprzyjająca, a w kraju ustabilizowała się sytuacja po przewrocie majowym, po wprowadzeniu złotówki i po zakończeniu wojny celnej z Niemcami (Wnęk 2006: 22). Barierę czytelnictwa stanowiły dość wysoki procent analfabetyzmu, niski standard wykształcenia oraz ubóstwo znacznej części społeczeństwa (Bieńkowska 2005: 236). Wejście w lata 30. wiązało się z kryzysem gospodarczym (1929-1933), który zahamował dynamiczny rozwój produkcji wydawniczej.

Wśród czynników determinujących charakter literatury dla dzieci i młodzieży w Polsce w okresie międzywojennym wymienić można dodatkowo upowszechnienie nowszych koncepcji wychowawczych (m.in. ruchu nowego wychowania), osiągnięcia psychologii rozwojowej i wychowawczej oraz wdrożenie nowego systemu edukacji narodowej.

Kres międzywojennego rynku wydawniczego wiąże się z wybuchem drugiej wojny światowej, a pięć lat później - powstania warszawskiego. Usytuowane po lewej stronie Wisły wydawnictwa, archiwa wydawnicze i księgarnie zostały w 1944 roku doszczętnie zniszczone (Gebethner 1989: 299-300). Tego roku doszło do przejęcia władzy przez Polską Partię Robotniczą, a rok później - do zakończenia wojny i wycofania uznania międzynarodowego dla rządu RP na uchodźstwie.

W dwudziestoleciu międzywojennym widoczny był ogólny spadek zainteresowania francuską literaturą piękną w Polsce. Jak stwierdził w 1934 roku Jan Lorentowicz:

[p]rzed wojną (i przez cały wiek dziewiętnasty) thumaczyliśmy najwięcej utworów francuskich, które stanowiły około 50\% wszystkich przekładów. 
Głód sensacji odsunął wydawców (a z nimi i tłumaczów) od literatury francuskiej (Lorentowicz 1934: 348).

Podobne zjawisko zaobserwować można również, jeśli chodzi o francuską literaturę dla dzieci i młodzieży. Choć 60 różnych oficyn opublikowało 265 wydań ponad 140 utworów francuskich, to jednak rozmiar importu z Francji zmniejszył się i znacząco zmienił charakter. O ile do XIX wieku najważniejsze francuskie utwory dla młodych czytelników były w większości tłumaczone, i to dość szybko po ukazaniu się oryginałów, o tyle w międzywojniu stanowiły już tylko około $3 \%$ produkcji dla młodych czytelników, a nowości - poza nielicznymi wyjątkami - nie docierały do Polski. O malejącym zainteresowaniu francuską literaturą dla dzieci i młodzieży świadczy to, że rezygnowali z niej najwięksi wydawcy, wcześniej aktywni w tej dziedzinie: Gebethner i Wolff, M. Arct, J. Mortkowicz, a oficyny, które świeżo włączały ją do oferty, np. Księgarnia Św. Wojciecha czy J. Przeworski, proponowały głównie reedycje klasyki i nieliczne wtórne utwory współczesne.

Polscy wydawcy międzywojenni najczęściej publikowali XIX-wieczną literaturę przygodową i fantastyczno-przygodową (Jules Verne, Louis Boussenard, Gustave Aimard, Alfred Assollant, Gabriel Ferry, Louis Gallet), realistyczną (Alphonse Daudet, Hector Malot) oraz literaturę dla dziewcząt (Sophie de Ségur, Sophie Victorine Perrault, Zénaïde Fleuriot, Mademoiselle de Martignat). Sięgali również do leżącej na pograniczu z literaturą popularnonaukową twórczości przyrodników (Jean-Henri Fabre, Ernest Candèze).

Dużo mniej popularni byli autorzy współcześni, a w dodatku - oprócz Charles'a Vildraca i może Andrégo Lichtenbergera - nie byli to pisarze mający wpływ na rozwój gatunku we Francji w tym okresie. Część z nich to twórcy krótkich podróżniczych opowiadań dla młodych czytelników o wyraźnie dydaktycznym celu (Charles Guyon, René Samoy, Henri Pellier, Maurice Farney), pojawiła się też twórczość kilku pisarzy inspirowanej Verne'em rozrywkowej literatury przygodowej i fantastyczno-przygodowej (Henri Allorge, André Laurie, Arnould Galopin, Gustave Le Rouge, Tancrède Vallerey), czasem inicjującej już nurt science fiction (J.-H. Rosny starszy) oraz kilkoro przedstawicieli literatury religijnej (Francis Jammes, Victor Marmoiton, Paule Fleury-Divès, Renée Zeller).

Polscy wydawcy nie zaproponowali czytelnikom niemal żadnych powstających we Francji nowości wyznaczających nowe trendy i docenianych przez tamtejszą krytykę. Nie dotarły do Polski książki dwóch nurtów, które nad Sekwaną rozwijały się najżywiej. Poza dwiema powieściami Vildraca 
w Polsce nie zaistniała więc tak zwana francuska fantasy, a nazwiska Léopolda Chauveau i Marcela Aymégo pozostały nieznane międzywojennym czytelnikom, którzy nie mieli też okazji dowiedzieć się, że André Maurois i Georges Duhamel tworzyli również dla dzieci. Młodzi Polacy nie poznali także nowoczesnych książek obrazkowych ${ }^{5}$ tego okresu, na przykład postrzeganej wówczas jako manifest awangardowego podejścia, wydanej w dużym, niemal kwadratowym formacie książki Macao et Cosmage ou l'Expérience du bonheur (1919) Édy-Legranda, ani równie nowatorskich z punktu widzenia grafiki książek o słoniu Babarze Jeana de Brunhoffa (Histoire de Babar, le petit éléphant, 1931).

Dość przypadkowe wybory wydawców mogły kształtować obraz francuskiej literatury dla dzieci i młodzieży jako przestarzałej i nieinteresującej. Być może literaturze tej zabrakło ambasadora, bo żaden z jej tłumaczy nie odgrywał takiej roli. Ówcześni wydawcy skupiali się przede wszystkim na literaturze polskiej, na przykład w katalogu Gebethnera i Wolffa, największego wydawcy tego okresu, w latach 1858-1937 przekłady stanowiły zaledwie 11,7\% (Muszkowski 1937). Duży wpływ miała też na pewno ogólna słabość francuskiej literatury dla dzieci i młodzieży w tym okresie, co znacznie utrudniało wydawcom dotarcie do książek bardziej nowatorskich, które nie stanowiły głównego nurtu.

\section{Polska Ludowa (1945-1989)}

Po II wojnie światowej losy polityki, rynku wydawniczego i literatury splotły się w sposób szczególnie ścisły. Znany z okresu międzywojennego rynek wydawniczy został w ciągu dekady zlikwidowany, a w jego miejsce powstał ruch wydawniczy sterowany przez aparat partyjno-państwowy. W 1944 roku utworzono w tymczasowym Polskim Komitecie Wyzwolenia Narodowego Wydział Cenzury, przekształcony następnie w Główny Urząd Kontroli Prasy, Publikacji i Widowisk, o którego faktycznych celach polskie społeczeństwo niewiele wiedziało, bo „wszelkie informacje o jego cenzorskiej działalności były strzeżone cenzorską tajemnicą" (Strzyżewski 2015: 29). Interesom ideologiczno-politycznym próbowano podporządkować wszystkie sfery

${ }^{5}$ Książka obrazkowa definiowana jest jako ta, która ,jest złożona z dwóch sposobów przedstawiania, dwu reprezentacji - obrazów i słów - stanowiących jeden tekst kulturowy" (Cackowska 2017: 11). 
społecznego obiegu książki: literacki proces twórczy, sferę wyboru tekstów do publikacji, sferę organizacji produkcji i rozpowszechniania książek, a nawet sferę konsumpcji książek - przez próby narzucenia sposobów ich rozumienia i interpretacji, na przykład za pomocą paratekstów czy też za pośrednictwem szkół (Kondek 1993: 17). Celem przejęcia kontroli nad obiegiem książki była chęć kształtowania zachowań czytelników za pomocą odpowiednio dobranego repertuaru literackiego.

Zasadą nowego układu wydawniczego, który funkcjonował bez większych zmian do 1989 roku, miała być specjalizacja poszczególnych oficyn w określonym rodzaju produkcji i wynikający z niej brak konkurencji. Publikowaniem literatury dla młodych czytelników zajmowały się zatem przede wszystkim: Iskry - specjalizujące się w literaturze dla młodzieży, i Nasza Księgarnia - specjalizująca się w literaturze dla dzieci (Siekierski 1992: 166).

Jak konstatuje Joanna Papuzińska, ,książka dziecięca w Polsce przeżywała okres względnej prosperity w latach 60 . Oferta tytułowa była wprawdzie dość ograniczona, ale nakłady poszczególnych tytułów wysokie, a standard edytorski bardzo przyzwoity" (1996: 157). Na przełomie lat 70. i 80. produkcja wydawnicza spadła, zarówno jeśli chodzi o liczbę tytułów, jak i o wielkość nakładów, pogorszyła się też edytorska jakość książek, czego przyczyną były rosnące problemy z przydziałami papieru dla wydawnictw, który dodatkowo był coraz gorszej jakości (Jamróz-Stolarska 2014: 42).

W Polsce Ludowej udział francuskiej literatury dla dzieci i młodzieży wśród wszystkich publikacji dla tej grupy czytelniczej jeszcze spadł w stosunku do okresu międzywojennego z około $3 \%$ do niespełna $2 \%$. W latach 1955-1989 francuski był czwartym w kolejności językiem (227 pozycji), z którego tłumaczono literaturę dla dzieci i młodzieży, za angielskim (699 pozycji, 5,9\%), rosyjskim wraz z językami krajów ZSRR (680 pozycji, 5,8\% wszystkich) oraz niemieckim (263 pozycji, 2,2\% ${ }^{6}$.

W tym okresie 39 wydawców opublikowało 355 wydań 122 francuskich utworów dla dzieci i młodzieży. Ilościowa przewaga Naszej Księgarni była bezsprzeczna - jej nakładem ukazało się ponad 60\% wszystkich wydań. Wydawcy proponowali polskiej młodzieży przede wszystkim utwory pisarzy XIX-wiecznych: przygodowo-podróżnicze powieści Jules’a Verne’a,

${ }^{6} \mathrm{O}$ takiej kolejności (angielski przed rosyjskim) decyduje zapewne brak danych dotyczących liczby przekładów z poszczególnych języków z pierwszej dekady po wojnie (19491954), kiedy udział przekładów z rosyjskiego był szczególnie duży. Dane z lat 1955-1989 pochodzą z czasopisma „Ruch Wydawniczy w Liczbach”, numery 1-35. 
realistyczną prozę Victora Hugo i Alphonse'a Daudeta, przygodowo-historyczną twórczość Alexandre'a Dumasa, Théophile'a Gautiera, Alfreda Assollanta, Paula Févala, Alfreda de Vigny i Louisa Galleta. Współczesną obyczajową literaturę francuską publikowała Nasza Księgarnia przede wszystkim w serii „Klub Siedmiu Przygód”, ale też poza nią (René Goscinny, Paul Berna, duet Boileau-Narcejac, George Nigremont, Robert Teldy Naïm, Colette Vivier i in.). Często wznawiany przez wydawnictwo Pax był Mały Ksiązę Antoine'a de Saint-Exupéry'ego. Do czytelników młodszych trafiały przekłady klasycznych bajek Charles'a Perraulta i Jeana de La Fontaine’a oraz współczesnych utworów fantastycznych Claude'a Aveline'a i Pierre'a Gamarry. W latach 80. - po długiej nieobecności - pojawili się francuscy autorzy katoliccy (Daniel-Rops, Carmen Bernos de Gasztold), popularna stała się też fantastyka naukowa (Gustave Le Rouge) i bajkowa (Pierre Gripari).

Jednak o ile zapożyczano sporadycznie twórczość z nurtu pogodnego wczesnego realizmu, o tyle nie dotarły do Polski powieści spod znaku zaangażowanego społecznie, bardziej pesymistycznego realizmu lat 70 . XX wieku, a jeśli się pojawiały - to przekierowywano je do czytelników dorosłych (np. Skok Bernarda Clavela). Nieznane w Polsce pozostały też awangardowe książki obrazkowe z lat 60., 70. i 80., które zrewolucjonizowały francuską literaturę dla dzieci i młodzieży (Nières-Chevrel 2009: 50, Van der Linden 2013: 208). Odbiegały one od czytelniczych przyzwyczajeń zarówno z punktu widzenia podejmowanych tematów, jak i formy, a ich celem nie było wyposażenie małego czytelnika w przydatną wiedzę, lecz wykształcenie wrażliwości na piękno. Nasza Księgarnia opublikowała tylko jedną książkę z tego nurtu, Ładny kwiat! Claude'a Roya z ilustracjami Alaina Le Folla, która pozostała ewenementem w jej repertuarze. Nigdy nie ukazały się w Polsce książki publikowane przez awangardowe oficyny Harlin Quist, Éditions des Femmes czy Le Sourire qui mord.

Na ukształtowanie takiego dość ograniczonego repertuaru wpływ miała specyfika układu wydawniczego w Polsce Ludowej oraz funkcjonowanie w tym okresie instytucji cenzury. Funkcjonariusze z ulicy Mysiej w Warszawie w pierwszej połowie lat 50. określili, jakie książki francuskie mogą być publikowane, a przez kolejne 45 lat wydawnictwa poszerzały ofertę tylko o „bezpieczne” nowości. Ogólnie preferowano inne kierunki zapożyczeń literackich, bo współczesna literatura francuska postrzegana była jako tradycyjna i płytka (Kuliczkowska 1957: 1383; Nowakowska 1968: 156).

Rezultatem chęci ścisłego kontrolowania społeczeństwa za pomocą repertuaru literackiego była jego jednorodność i swoista hermetyczność, 
przejawiająca się - poza monotonią oferty - również w wykorzystywaniu tylko współczesnych ilustracji polskich artystów. Ilustracje artystów francuskich zachowano jedynie w nielicznych przypadkach (Saint-Exupéry, cykl o Mikołajku, XIX-wieczne grafiki w powieściach Verne’a). Preferowano również współczesne przekłady, w wyniku czego nie ukazywały się wznowienia tłumaczeń wcześniejszych (por. Paprocka 2012).

\section{Rzeczpospolita (od roku 1990)}

W 1990 roku zlikwidowano cenzurę i zalegalizowano prywatną działalność gospodarczą, czego skutkiem był szybki demontaż pozostającego pod kontrolą państwa ruchu wydawniczego, idący w parze z kształtowaniem opartego na konkurencji rynku książki w Polsce. Lata 90. to burzliwy okres przejściowy, ogromna „eksplozja energii” (Klukowski, Tobera 2010: 21), „euforia wolnego rynku” (Marecki, Sasin 2015: 123), które pociągnęły za sobą „boom wydawniczy” (Kitrasiewicz, Gołębiewski 2005: 277). Popyt był wówczas ogromny, bo głodni książki odbiorcy kupowali wydawane w setkach tysięcy niedostępne wcześniej tytuły, przede wszystkim anglojęzycznej literatury rozrywkowej.

Pierwszy okres transformacji wiązał się jednak z głębokim kryzysem książki dla dzieci i młodzieży, określanym mianem ,potopu”, bo „wysoka fala przemian” zalała wówczas rynek, ,zatapiając” dawne wydawnictwa państwowe wraz z ich wykształconymi przez wiele lat praktykami wydawniczymi (Świerczyńska-Jelonek i in. 2008: 7). Nasza Księgarnia i Iskry, od 1992 roku działające jako spółki z ograniczoną odpowiedzialnością, zyskały konkurencję w postaci nowych oficyn, które traktowały wydawanie książek dla dzieci jako sposób na szybki zysk. Ich produkty - jak opisuje Papuzińska - „dosłownie zmiotły z rynku «szarobure» edycje z lat poprzednich” (1996: 157). Po ubogich latach 80. czytelnicy skierowali się ku produktom wcześniej niedostępnym. Rozchwytywane były książki obrazkowe dla dzieci najmłodszych, popularne wydawnictwa Disneya, masowe edycje klasyki baśniowej, a także książki popularnonaukowe. Jak to podsumowuje Olech, „,[p]ierwsza dekada wolnego rynku była jak nieumiarkowane obżarstwo po latach surowej diety" (2008: 192).

W przyspieszonym okresie dziesięciu lat chaotyczny początkowo rynek książki uporządkował się, a z początkiem nowego milenium rozpoczęła się 
w Polsce stopniowa jego profesjonalizacja ${ }^{7}$, idąca w parze z konsolidacją po ogromnym rozdrobnieniu typowym dla początku lat 90 .

Rok 2000 bywa wskazywany jako data przełomowa również w odniesieniu do rynku książki dla dzieci i młodzieży. Jak zauważa Grzegorz Leszczyński, doszło wtedy do ,przełamani[a] dominacji literatury tłumaczonej nad twórczością polską oraz ukształtowani[a] atrakcyjnej oferty edytorskiej" (2007: 33-34). Choć pierwsze zjawisko okazało się przejściowe, bo wkrótce odsetek przekładów wzrósł nawet do $64 \%$ w roku $2008^{8}$, to drugie pozostało faktem, i to coraz bardziej widocznym.

W omawianym okresie udział francuskiej literatury dla dzieci i młodzieży wśród wszystkich publikacji dla tej grupy czytelniczej wzrósł z 2\% w okresie Polski Ludowej do 7\% w latach 90., a potem nieco spadł do 5,5\% w pierwszym piętnastoleciu XXI wieku. Pierwsze miejsce zajmowały przekłady z angielskiego (7839 wydanych pozycji, 29,5\%), francuski natomiast - choć liczbowo daleko za nim (1622 pozycje, 6,1\%) - usytuował się na miejscu drugim, przed niemieckim (1355 pozycji, 5,1\%), włoskim (669 pozycji, $2,5 \%$ ), szwedzkim (582 pozycje, $2,2 \%$ ), hiszpańskim (471 pozycji, 1,8\%) i rosyjskim (187 pozycji, $0,7 \%)^{9}$.

W latach 1990-2014 nastąpił wyraźny wzrost importu literatury dla dzieci i młodzieży z Francji: nakładem 160 polskich wydawnictw ukazało się aż 1285 wydań polskich przekładów i adaptacji ponad 680 utworów francuskich. Tradycyjnie importowana była proza, przede wszystkim XIX-wieczna - niepodzielnie królował Verne, ale często wznawiany był też Alexandre Dumas. Do współczesnej prozy wydawcy sięgali mniej chętnie, choć powracają nazwiska pisarzy takich, jak Éric-Emmanuel Schmitt, Gudule, Thierry Lenain, Michel Amelin, Jean-Philippe Arrou-Vignod, Valérie Dayre, Marie Desplechin. Ogromnie popularne stały się bajki Perraulta i La Fontaine'a - w przekładach, ale też w różnych adaptacjach i przeróbkach.

Nowością w literackim imporcie z Francji stały się książki obrazkowe, które od lat 90. XX wieku stały się francuskim „towarem eksportowym” (Clavreul 2015: 45). Do Polski początkowo sprowadzano na prawach licencji niemal wyłącznie komercyjne książki tego rodzaju, ale od początku XXI wieku, kiedy na rynku zaczęły działać niewielkie, awangardowe wydawnictwa

${ }^{7}$ Marcin Rychlewski (2013) początek profesjonalizacji rynku książki sytuuje w roku 2005.

8 Zob. „Ruch Wydawniczy w Liczbach”, nr 54.

9 Dane na podstawie: „Ruch Wydawniczy w Liczbach”, numery 36-60. 
zwane „lilipucimi”, pojawiły się również propozycje bardziej artystyczne (Biernacka-Licznar, Paprocka 2016). Ilościowo najwięcej opublikowano utworów Émilie Beaumont i Nathalie Bélineau, Pierre'a Couronne'a, Pascale Védère d'Aurii, Aline de Pétigny, Nadii Berkane, Ann Rocard oraz Sandrine Deredel Rogeon. Jednak warte wzmianki są też nazwiska cenionych i nagradzanych twórców publikujących we Francji, takich jak Hervé Tullet, Emmanuelle Houdart, Serge Bloch, Jean-François Martin, Jennifer Yerkes, Benjamin Chaud czy Blexbolex. Ostatnie ćwierćwiecze stanowi pierwszy od 1918 roku okres, kiedy polscy czytelnicy mieli możliwość poznania nie tylko twórczości francuskich pisarzy dla dzieci i młodzieży, ale również ilustratorów tworzących dla tej grupy wiekowej, bo książka dziecięco-młodzieżowa po raz pierwszy na szerszą skalę importowana była jako całość, a nie wyłącznie jako tekst.

\section{Podsumowanie}

Oparte na analizie wykazu bibliograficznego badanie pozwoliło z jednej strony na ocenę i opis rzeczywistego rozmiaru, charakteru i miejsca obecnej za sprawą przekładów francuskiej literatury dla dzieci i młodzieży w Polsce w ostatnim stuleciu, a z drugiej - na pogłębienie wiedzy o mechanizmach przyswajania literatury obcej w kontekście diachronicznym.

W badanym okresie przekłady francuskiej literatury dla młodych czytelników - nie tak dawno stanowiące podstawę polskiej oferty - stanowiły już tylko niewielki jej odsetek (od 2 do $7 \%$ w poszczególnych okresach). Za wybór tytułów do publikacji odpowiadali polscy wydawcy przekładów, a ich decyzje były warunkowane szerokim kontekstem społeczno-politycznym. W okresie Polski Ludowej podporządkowane były przede wszystkim ideologii, a w okresie międzywojennym i w pierwszej dekadzie wolnego rynku służyć miały głównie osiąganiu zysków ekonomicznych. Ogólnie wydawcy preferowali reedycje francuskiej klasyki, za to niezbyt chętnie stawiali na nowości, a jeśli się na nie decydowali, to nie były to utwory wyznaczające nowe trendy - poza przejściową modą na „mikołajki”, w wyniku której powstawać zaczęły polskie utwory i serie wydawnicze inspirowane cyklem Sempégo i Goscinnego.

Obraz francuskiej literatury dla dzieci i młodzieży, który na podstawie przekładów mogli sobie tworzyć polscy odbiorcy w ostatnich stu latach, był w dużej mierze niepełny i zniekształcony, niczym odbicie w krzywym 
zwierciadle. Na skutek dość przypadkowych wyborów wydawców niektóre nurty stawały się bardziej lub mniej widoczne niż w kulturze oryginału. Na przykład twórczość Verne’a i kilkorga innych klasyków, podobnie jak cykl o Mikołajku - wielokrotnie wznawiane i „reutylizowane” - jawić się mogły polskim czytelnikom jako najistotniejsze części tej literatury. Słabo obecne pozostały natomiast inne kierunki, jak żywo rozwijająca we Francji literatura obyczajowa, która w Polsce pojawiała się sporadycznie. Istnienia jeszcze innych trendów polski odbiorca pozostawał w ogóle nieświadomy, bo wydawcy przekładów w swoich wyborach całkowicie je pomijali. Dotyczy to przede wszystkim książek obrazkowych, stanowiących od końca XIX wieku istotną część francuskiej literatury dla dzieci i młodzieży. Choć we Francji odgrywały one nierzadko rolę awangardy literackiej i artystycznej, w Polsce pozostały nieznane do roku 1989, a w latach 90. importowano tylko mniej wartościowe pozycje. Dopiero działający od początku XXI wieku wydawcy lilipuci udostępnili polskim czytelnikom część współczesnych artystycznych książek obrazkowych znad Sekwany. Ich wybory mogły przyczynić się do zmiany obrazu francuskiej literatury dla dzieci i młodzieży wśród polskich odbiorców, bo dzięki nim nad Wisłą pojawiły się propozycje świeże i odważne, nowatorskie pod względem formalnym i tematycznym.

Otwarta - i warta osobnego badania - pozostaje kwestia, jak na obraz francuskiej literatury dla dzieci i młodzieży u polskich czytelników wpływały tekstowe wybory tłumaczy, w których ręce trafiały utwory wyselekcjonowane przez wydawców przekładów w ciągu ostatniego wieku.

\section{Bibliografia}

Baker M. 2014. The Changing Landscape of Translation and Interpreting Studies, w: S. Bermann, C. Porter (eds.), A Companion to Translation Studies, Chichester: Wiley-Blackwell, s. 15-27.

Bębenek S. i in. (red.). 1977-1978. Bibliografia literatury tlumaczonej na język polski wydanej w latach 1945-1976, t. I-II, Warszawa: Czytelnik.

Bębenek S. i in. (red.). 1983. Bibliografia literatury thumaczonej na język polski. 19771980, t. III, Warszawa: Czytelnik.

Bieńkowska B. 2005. Ksią̇ka na przestrzeni dziejów, Warszawa: CEBIiD im. H. Radlińskiej.

Biernacka-Licznar K., Paprocka N. 2016. Polscy wydawcy lilipuci jako idea-makers?, „Przekładaniec” 32, s. 145-162. 
Brown P. 2008. A Critical History of French Children's Literature, t. 2: 1830-Present, New York - London: Routledge.

Cackowska M. 2017. Wspótczesna książa obrazkowa-pojęcie, typologia, badania, teorie, konteksty, dyskursy, w: M. Cackowska, H. Dymel-Trzebiatowska, J. Szyłak (red.), Ksiażka obrazkowa. Wprowadzenie, Poznań: Instytut Kultury Popularnej, s. 11-48. Clavreul É. 2015. Principaux contours du paysage éditorial du livre de jeunesse, w: F. Legendre (dir.), Bibliothèques, enfance et jeunesse, Paris: Electre - Éditions du Cercle de la librairie, s. 41-46.

Escarpit D. (dir.). 2008. La littérature de jeunesse. Itinéraires d'hier à aujourd'hui, Paris: Magnard.

Gebethner S. 1989. Postowie, w: J. Gebethner, Młodość wydawcy, Wrocław i in.: Zakład Narodowy im. Ossolińskich, s. 293-305.

Gołębiewski Ł. 2010. Powód do dumy. Rynek książki po 1989 roku, w: P. Dobrołęcki (red.), Dwudziestolecie wolnego rynku ksiązki w Polsce (1989-2009), Warszawa: Biblioteka Analiz, s. 10-12.

Jamróz-Stolarska E. 2014. Serie literackie dla dzieci i młodzieży w Polsce w latach 1945-1989: produkcja wydawnicza i uksztaltowanie edytorskie, Warszawa: SBP.

Kaniowska-Lewańska I. 1973. Literatura dla dzieci i młodzieży do roku 1864. Zarys rozwoju, wybór materiału, Warszawa: PZWS.

Kitrasiewicz P., Gołębiewski Ł. 2005. Rynek książki w Polsce 1944-1989, Warszawa: Biblioteka Analiz.

Klukowski B., Tobera M. 2010. Przeksztatcenia i zaniechania. Oficyny państwowe i prywatne w początkach transformacji (1989-1995), w: P. Dobrołęcki (red.), Dwudziestolecie wolnego rynku książki w Polsce (1989-2009), Warszawa: Biblioteka Analiz, s. 13-21.

Kondek S.A. 1993. Władza i wydawcy. Polityczne uwarunkowania produkcji ksiażek w Polsce w latach 1944-1949, Warszawa: Biblioteka Narodowa.

Krassowska B., Grefkowicz A. (oprac.). 1995. Bibliografia literatury dla dzieci i młodzieży 1918-1939. Literatura polska i przeklady, Warszawa: Biblioteka Publiczna m.st. Warszawy.

Kuliczkowska K. 1957. O strachach i o... Martali, „Nowe Książki” 22(182), s. 1383.

Leszczyński G. 2007. Literatura dla młodych odbiorców 1990-2006, „Guliwer” 1,33-34. Lorentowicz J. 1934. Nasze przekłady literackie, „Nowa Książka” 1(8), s. 345-350.

Łachaciński W., Zydorczak A. 1998. Bibliografia polskich przekładów utworów Juliusza Verne'a, Pruszków: Ajaks (bibliografia kontynuowana i uzupełniana on-line: http:// verne.bbo.pl/bibliografia/).

Łasiewicka A., Neubert F. (oprac.). 1971. Bibliografia literatury dla dzieci 1945-1960: przektady, adaptacje, Warszawa: SBP.

Marecki P., Sasin E., 2015 „, Ciężkie książki” vs. , lekka i tania informacja”. Warunki produkcji książki w Polsce po 1989 roku, „Przegląd Kulturoznawczy” 2(24), s. 108-125.

Muszkowski J. 1937. Z dziejów firmy Gebethner i Wolff 1858-1937, Warszawa i in.: Feliks West.

Nières-Chevrel I. 2009. Introduction à la littérature de jeunesse, Paris: Didier Jeunesse. 
Nikliborc A. 1981. Od baśni do prawdy. Szkice z dziejów literatury zachodniej dla dzieci i młodzieży, Warszawa: Nasza Księgarnia.

Nowakowska O. 1968. Światowa książka dziecięca w Polsce i polska książka w świecie, w: S. Aleksandrzak (red.), Kim jesteś, Kopciuszku, czyli o problemach współczesnej literatury dla dzieci i młodzieży, Warszawa: Nasza Księgarnia, s. 155-169.

Olech J. 2008. Ilustracja polska po potopie, w: D. Świerczyńska-Jelonek, G. Leszczyński, M. Zając (red.), Po potopie. Dziecko, książa i biblioteka w XXI wieku: Diagnozy i postulaty, Warszawa: SBP, s. 189-194.

Ottevaere-Van Praag G. 2000. Histoire du récit pour la jeunesse au XXe siècle (19292000), Bruxelles: Peter Lang.

Paprocka N. 2012. Traducteurs polonais de la littérature de jeunesse française: pour un portrait collectif, „Romanica Wratislaviensia” 59, s. 155-174.

Paprocka N. 2018a. Bibliografia polskich przekładów i adaptacji francuskiej literatury dla dzieci i młodzieży wydanych w latach 1918-2014, Kraków: Universitas.

Paprocka N. 2018b. Sto lat przekładów dla dzieci i młodzieży w Polsce. Francuska literatura dla młodych czytelników, jej polscy wydawcy i ich strategie (1918-2014), Kraków: Universitas.

Papuzińska J. 1996. Polska literatura dziecięca $w$ latach dziewięćdziesiatych, w: Almanach polskiej kultury dziecięcej, Hamburg: Katholische Akademie, s. 157-164.

Popa I. 2010. Traduire sous contraintes. Littérature et communisme (1947-1989), Paris: CNRS.

Pym A. 1998. Method in Translation History, Manchester: St. Jerome.

Rychlewski M. 2013. Książka jako towar-książka jako znak. Studia z socjologii literatury, Gdańsk: Katedra.

Siekierski S. 1992. Książka literacka. Potrzeby społeczne i ich realizacja $w$ latach 1944-1986, Warszawa: Wydawnictwo Naukowe PWN.

Skibińska E. 2015. Przekłady francuskiej prozy oświeceniowej na polskim rynku wydawniczym w latach 1945-2010. Możliwości i ograniczenia metody ilościowej w badaniach nad przekładem, ,Wiek Oświecenia” 31, s. 239-258.

Strzyżewski T. 2015. Wstęp, w: T. Strzyżewski, Wielka księga cenzury PRL w dokumentach, Warszawa: Prohibita, s. 29-40.

Świerczyńska-Jelonek D., Leszczyński G., Zając M. (red.). 2008. Po potopie. Dziecko, książka i biblioteka $w$ XXI wieku: Diagnozy i postulaty, Warszawa: SBP.

Van der Linden S. 2013. L'albo illustrato in Francia dopo gli anni Sessanta: uno scenario caleidoscopico, w: G. Grilli (a cura di), Bologna : cinquant'anni di libri per ragazzi da tutto il mondo, Bologna: Bolonia University Press, s. 205-226.

Wnęk J. 2006. Polskie przekłady literatury zagranicznej 1918-1939, Kraków: Wydawnictwo MCDN.

Wolf M. 2010. Sociology of Translation, w: Y. Gambier, L. van Doorslaer (eds.), Handbook of Translation Studies, t. 1, Amsterdam-Philadelphia: John Benjamin, s. 337-343. 